\title{
РЕЗУЛЬТАТИВ У СИСТЕМІ ДІССЛІВНОЇ СЕМАНТИКИ (НА МАТЕРІАЛІ УКРАЇНСЬКОЇ МОВИ)
}

\author{
ЮЛІЯ ГОЛОЦУКОВА \\ Маріупольський державний університет, Маріуполь - Україна
}

\section{FORMA REZULTATYWNA W SYSTEMIE SEMANTYKI CZASOWNIKA (NA MATERIALE JĘZYKA UKRAIŃSKIEGO)}

\author{
JULIA HOLOCUKOVA \\ Mariupolski Uniwersytet Państwowy, Mariupol — Ukraina
}

STRESZCZENIE. Artykuł poświęcony jest analizie form rezultatywnych w języku ukraińskim, badaniu ich rodzaju formalno-gramatycznego oraz specyfiki funkcjonowania. Wyróżniono typy form rezultatywnych, przeanalizowano korelację form rezultatywnych z innymi kategoriami gramatycznymi oraz leksykalno-gramatycznymi. Zdefiniowano stabilne i niestabilne elementy sytuacji.

\section{RESULTATIVE IN THE SYSTEM OF VERB SEMANTICS (ON THE MATERIAL OF THE UKRAINIAN LANGUAGE)

\author{
YULYA HOLOTSUKOVA \\ Mariupol State University, Mariupol — Ukraine
}

\begin{abstract}
The article deals with the research of the resultatives of the Ukrainian language: the formal-grammatical types, the peculiarities of their functioning. The types of the forms of resultatives are distinguished, the correlation of the resultative with other lexical-grammatical and grammatical categories is analyzed. Stable and unstable components of the resultative situation are defined.
\end{abstract}

$\mathrm{P}$ езультатив у різних аспектах досліджували такі лінгвісти, як І. Вихованець, О. Бондарко, К. Городенська, А. Загнітко, Ю. Князєв, Ю. Маслов, В. Недялков, В. Плунгян, Г. Сильницький, О. Холодович, С. Яхонтов та ін. Категорія результативності виражає аспектуальне значення дієслова: це найбільш давня дієслівна категорія, оскільки дослідники доводять первинність аспектуальних значень у системах слов'янських та германських мов. Способи вираження категорії результативності змінювалися разом із розвитком мови. Спочатку це були кореневі основи. 3 часом окреслену функцію взяли на себе темпоральні засоби, словотворчі, лексичні (граничні дієслова) та система синтаксичних засобів.

У межах аспектуальної категорії результативність розглядали Н. Авілова, О. Бондарко, В. Виноградов, М. Гловінська, О. Ісаченко, Ю. Маслов, І. Мучник, М. Шелякін та ін. О. Потебня, І. Вихованець, А. Загнітко вважають, що результатив належить до категорії стану дієслова.

Мета цієї наукової розвідки — репрезентація структурно-лінеарної і функційно-семантичної типології результатива в системі дієслівної семантики. Реалізація поставленої мети передбачає розв'язання таких завдань: розгляну- 
ти структурне й семантичне співвідношення / неспіввідношення результатива й категорії транзитивності / інтранзитивності, виявити основні виміри взаємодії результатива й аспекту, закономірності корелятивності категорійної семантики результатива й темпоральної категорії дієслова, взаємовияв та взаємозумовленість результатива та особи дієслова.

Одним із визначальних чинників, що зумовлюють утворення результативних форм, є транзитивність / інтранзитивність вихідного дієслова. Українські результативи переважно утворені від транзитивних дієслів і зберігають водночас транзитивність. Для української мови характерні такі закономірності збереження похідним результативом синтаксичних і семантичних інтенцій твірного результатива від транзитивного дієслова:

- результатив від транзитивного дієслова керує іменником у знахідному (семантика об'єкта) та орудному (семантика інструмента) відмінках: Одежа, руки в них забруднені фарбою та клеєм (Леся Українка); Вся сторона, щзо від сония, горіла рожевим світом, - здавалося, вона була викрашена такою краскою (Панас Мирний); Тіснота, галас, лайка, гуркіт возів, ізновучорна дорога в гори, блискання іскор, викресаних підковами, клекіт копит (О. Гончар); Дивлюся ранком - вже заволочено серпанком сіреньким небо, далі став помалу й дошик накрапати (Леся Українка); Величаві тріумфальні ворота закосичено щедро зеленим віттям кедрини й папороті (П. Козланюк); Закручено руки в ремені, і ноги в колодки забиті (А. Малишко) та ін.;

- результатив від транзитивного дієслова керує іменником у родовому відмінку (семантика об'єкта) при запереченні: Казарка була бита на крило, а так більше нічого в неї прострелено не було (Остап Вишня); Не піднесено ӥхнього mpiyмфу до рівня свята (Ю. Збанацький) і под.;

- результатив від транзитивного дієслова керує іменником у родовому партитивному відмінку. Такі транзитиви активно продукують форми на -но, -mo, що характерні літературній нормі української мови: Федір Королевич був колишній арсенальський кадровий робітник, покликаний до армії в периий день війни - ще до того, як усіх арсенальських робітників заброньовано (Ю. Смолич); Нашій вельможній шляхті завдано нечуваної ганьби (З. Тулуб) і таке ін.;

- результатив на -но, -то від транзитивного дієслова передбачає регулярний вияв інфінітива в правобічному найближчому оточенні, що постає рівноконкурентним знахідному об'єкта: Піднявщись кількома східиями на площадку, Гузь ввійшов у передпокій, де йому було запропоновано зняти пальто (М. Гонта); Командувати червоним фронтом призначено Фрунзе, - шорстко проказав далі старий (Ю. Яновський); Йому дано було особисто заглянути у скриньку Пандори (Н. Рибак).

Результативи української мови мотивовані інтранзитивами, як-от: $B$ коридорах надто чисто прибрано (Іван Ле); Накурено так, щзо дихати важко було; страшенно смерділо горілкою... (Панас Мирний); Невеличкий перон, видно давно метений і невідомо коли ремонтований, швидко спустів (Ю. Збанацький) і под.

Традиційно в лінгвістиці аспектуальну категорію визначають так: „Вид $€$ певною граматичною категорією слов'янських мов, саме категорією доконаності — недоконаності (перфективності — неперфективності) дієслівної дії"1; аспект - це граматична категорія, що узагальнено вказує, як протікає

${ }^{1}$ Ю. С. Маслов, Глагольный вид в современном болгарском литературном языке (значение и употребление), [в:] Вопросы грамматики болгарского литературного языка, Москва 1959, с. 157. 
або як розподілена в часі позначена дієсловом дія. Хоча й темпоральні, й аспектуальні значення „пов’ язані із загальною ідеєю часу”2, але вона зреалізована порізному. На відміну від темпоральної категорії, аспектуальна не має дейктичних функцій: ідея часу виражена інакше — „як внутрішня інгерентна властивість самої позначуваної дії". У лінгвістиці загальноприйнятою є думка про аспект як про „внутрішній час” дії.

Під „характером протікання та розподілу дії в часі” розуміють такі аспектуальні ознаки, як обмеженість / необмеженість граничністю, наявність / відсутність внутрішньої межі, дія як процес або обмежений границею цілісний факт, кратність, тривалість, фазовість дії, актуальність наслідків дії для пізнішого темпорального плану (перфектність), відмінність між власне дією, станом і відношенням. Сукупність цих ознак називають аспектуальністю.

Основним засобом вираження вказаних значень $є$ перфективи та імперфективи. Ці значення можуть бути передані й способами дії - лексикограматичними розрядами. Проте роль центру в мовній системі відіграє саме граматична аспектуальна категорія.

Отже, категорія аспектуальності — це база для аналізу аспектуальних характеристик предикатів. Для української мови семантичною домінантою $є$ „наявність / відсутність внутрішньої межі”, точніше, „спрямованість дії на результат / досягнення результату”, тому найповніше й найпослідовніше аспектуальна категорія реалізується в рамах граничних (результативних) дієслів, або дієслів із логічною (природною) граничністю та, відповідно, результативів.

Так, одним із двох головних чинників, окрім транзитивності дієслів, від яких залежить можливість утворення результативних форм, є аспектуальна приналежність вихідного дієслова. Результативні форми утворені переважно від граничних перфективних дієслів: класти $\rightarrow$ закласти $\rightarrow$ закладений (закладено) - Серію потужних зарядів уже закладено в моноліт, у щзойно пробурені шпури (О. Гончар); бомбити $\rightarrow$ розбомбити $\rightarrow$ розбомблений (розбомблено) - Нічого певного не знає він про їхній смертний час, про те, як тонуло розбомблене фашистськими літаками транспортне судно (О. Гончар); пити $\rightarrow$ випити $\rightarrow$ випитий (випито) — Зайво випитий ківш угорського вина з ніжних рук молодої Барбари... ламав священні вояцькі звичаї (Іван Ле); дряпати $\rightarrow$ видряпати $\rightarrow$ видряпаний (видряпано) — Тим часом стали надходити відповідi на його грамоти. Найперше від Судислава. Прислав бересту з видряпаними костяним писалом кривулями (П. Загребельний); бомбити $\rightarrow$ розбомбити $\rightarrow$ розбомблений (розбомблено) - Переправу розбомблено. Починають знову [бомбити] (О. Гончар) і под.; і неграничних перфективних дієслів: бренькати $\rightarrow$ пробренькати $\rightarrow$ пробреньканий (пробренькано) - Шопена вальс, пробреньканий невміло / На піаніно. О! Даль яку він срібну відслонив / Мені в цеей час вечірньої утоми (М. Рильський); будити $\rightarrow$ пробудити $\rightarrow$ пробуджений (пробуджено) - Неначе пробуджені від сну надзвичайністю того, щзо сподіялось, люди набули раптом немовби нового бачення світу (О. Довженко); бинтувати $\rightarrow$ забинтувати $\rightarrow$ забинтований (забинтовано) - Од страшного болю я застогнав, схопив себе за обличчя: воно було вже забинтоване (Ю. Яновський); боронити $\rightarrow$ заборонити $\rightarrow$ заборонений (заборонено) — Чи знаєте, щзо , Зоря” $i$,„Дзвінок” вже заборонені у Росії? (Леся Українка) тощо.

${ }^{2}$ Ю. С. Маслов, К основаниям сопоставительной аспектологии, [в:] Вопросы сопоставительной аспектологии, Ленинград 1978, № 1, с. 5.

${ }^{3}$ Там же, с. 7. 
Результативи від граничних і неграничних імперфективів характеризуються відсутністю факту кінця дії; залежно від контексту такі конструкції можуть набувати результативного значення, порівн.: Ведмідь скакав, і хмарами пливла під сонцем персть, вибивана ногами (М. Драй-Хмара) - лексема вибивана, утворена від імперфектива вибивати, не має факту кінця дії, але в контексті набуває значення „вибита” як наслідок попередньої дії вибивати $\rightarrow$ вибити $\rightarrow$ вибита; [Жандарм:] Я полюбив отсю бідолаху, Анну, сироту..., кривджену нелюдами-братами (І. Франко) — лексема кривджена, утворена від імперфектива кривдити, не має факту кінця дії, але в контексті набуває значення „скривджена” як наслідок попередньої дії; Виснажений, знесилений, змучений. I самому лихо, і кінь морений так насилу-насилу допхавсь додому аж опівночі (Г. Квітка-Основ' яненко) — лексема морений у контексті набуває значення „зморений” як наслідок дії „зморити”; Бійціі, товплячись біля вікон, з радістю впізнавали штурмовані свої верховини, голосно звертались до них, як до живих icmom (О. Гончар) — лексема штурмовані, утворена від імперфектива штурмувати, не має факту кінця дії, але в контексті набуває значення результату попередньої дії; Перегукуючись, лісоруби складали в стоси останні вогкі від соку кряжі, гонтарі досортовували шпунтовану гонту (М. Стельмах) - лексема шпунтована, утворена від імперфектива шпунтувати, не має факту кінця дії, але в контексті набуває значення результату попередньої дії; А його не кликано, не приманювано, сам прибіг. (П. Загребельний) - кликано в значенні „покликаний”, приманювано — „приманено”; - Гляньте на цүих орлів, — казав, задумано розглядаючи їх, Журба, - щз не хлопець, то сила, розум, талант... Один в один... Це ж усе найкращий иявіт народу, вибираний, пересіяний! (С. Васильченко) - вибираний у значенні „вибраний”; [Семен Мельниченко:] Як тут гарно, скільки усякого цзвіту! I верба, що вдвох посадовили, розрослась навдивовижу: мабуть, часто поливана (М. Кропивницький) - лексема поливана завдяки першій частині речення набуває результативного значення та ін.

Результативність „у межах аспектуальності пов’язана також із темпоральною семантикою"4. В українському мовознавстві в рамах результативного значення розмежовують три темпоральні типи. Результативи аналітично виражають значення часу, яке виявлюване тільки у форм дієслова бути, що набуває статусу регулярного часового маркера.

О. Ісаченко вважає, що пасивний дієприкметник має форми всіх трьох часів зі статальним значенням ${ }^{5}$. На думку Л. Леннгрен, перфектне значення (iз різними його відтінками), що належить до теперішнього часу, може бути транспоноване в минулий і майбутній часові плани. Ю. Маслов також уважає, що „форми 3 «було» $\mathrm{i}$ «буде» можуть виражати перфектну семантику”6. А. Ломов зробив важливе зауваження, що стосується категорії результативноті, „значення результативності є регулярним: воно проходить крізь усі три часові плани й у зв'язку з цим опиняється ніби винесеним за дужки щодо темпоральної категорії'”.

${ }^{4}$ Ю. С. Маслов, Очерки по аспектологии, Ленинград 1984, с. 195.

${ }_{5}^{5}$ А. В. Исаченко, Грамматический строй русского языка в сопоставлении с словачким. Морфология, Братислава 2003, ч. 2.

${ }^{6}$ Ю. С. Маслов, Результатив, перфект и глагольный вид, [в:] Типология результативныхх конструкиий, Ленинград 1983, с. 198.

${ }^{7}$ А. М. Ломов, Категория вида, способы глагольного действия и базисные аспектуальные группь, [в:] Вопросы современного русского языка и методики его преподавания в педагогическом вузе, Курск 1974, ч. 1, с. 61. 
Виділяємо тричленну темпоральну систему результативів. Форма минулого часу результатива має значення передування основній дії. Вона вказує на актуальність результату попередньої дії до певного моменту, за точку відліку береться момент у минулому 8 . Конструкція показує, що не тільки дія, але й стан, що виник як наслідок цієї дії, належить до минулого: За рішенням херсонських властей $i$ за бажанням самих тавричан загін незабаром було перейменовано в Перший Таврійський револючійний полк (О. Гончар); Стріляли на стрільбах, кололи штиками ті самі опудала, щуо їх безліч разів уже було переколото курсантами піхотного училищза (О. Гончар); Багато беріз було перепсовано кулями (Ю. Яновський); Його голова ... була переповнена думками про вибори (Л. Мартович); Через голі Робінзонові плечі була перечеплена якась руда латка (Ю. Збанацький); Олександр переконався, щуо до кампанї з Наполеоном Росія зовсім була не підготовлена (І. Кочура) та ін.

Іноді важко визначити значення форми. На думку Ю. Князєва, співвідносні $з$ предикативними формами на -но, -то дієприкметникові форми мають лише результативне значення, тому можливість заміни ними форм на -но, -то може вказувати на результативне значення останньої ${ }^{9}$ Йона атаковано зо всіх боків: він мусить згодитися, щзоб його дочку оглянули (М. Коцюбинський) - атаковано = атакували — дія; Хоч вересень, а спіє жито, / Ячмінь колосся підійма, / Отут було кілочки вбито, / А зараз їх чомусь нема (А. Малишко) - вбито = вбиті, - результат; Бачура зрозумів, щзо суперечку виграно, щчо Вовченко здав$c я($ В. Коцюба $)$ - виграно = виграв - дія тощо.

Майбутній результативний вимір означає, що дія та їі результативний стан здійсняться після моменту мовлення або іншого моменту, узятого за точку відліку. О. Шахматов уважав форми 3 дієслівною зв'язкою буде відповідниками простого майбутнього доконаного виду. Однак аспектологи визнають можливість передачі в майбутньому результативного значення здійсненої дії (Ю. Князєв, А. Ломов, В. Маслова та ін.). Поєднання результатива зі зв'язкою буде в українській мові явище нерегулярне: відсутня практична необхідність виражати результативний стан у майбутньому.

Услід за Д. Вечорек виділяємо такі футуральні перфективи ${ }^{10}$ :

- футуральні перфективи, що характеризуються яскравою перфектною семантикою, яка виявляється в особливих синтаксичних умовах, тобто коли футуральна форма входить до складу підрядно-умовної або підрядно-часової частин складного речення: I сказав, щзо він, як тільки открито буде полювання, одразу на иілий місяцьь залізе в комиші (М. Хвильовий) — результатив буде открито повідомляє про майбутню дію відкривати $\rightarrow$ відкрити та їі результат відкритий (відкрито); Коли комбат попередив, щзо тільки-но кулеметний вогонь противника буде дезорганізовано, з фронту готель атакують щзе кілька штурмових груп (О. Гончар) — результатив буде дезорганізовано повідомляє про майбутню дію дезорганізовувати $\rightarrow$ дезорганізувати та ії результат дезорганізований (дезорганізовано) та ін. Значення футуральної перфектності в наведених прикладах визначуване не тільки особливим синтаксичним контекстом, але й допоміжною формою буде. Іноді зміст належить до майбутнього, тоді як перфектна конструкція репрезентована презентним перфектом. Як наслідок

${ }^{8}$ В. П. Недялков, С. Е. Яхонтов, Типология результативных конструкиий: результатов, статив, пассив, перфект, Ленинград 1983, с. 153-154.

9 Там же, с. 149.

${ }^{10} \mathrm{D}$. Wieczorek, Ukrainskij pierfekt na -no, -to na fonie polskogo pierfekta, Wrocław 1994, s. $20-32$. 
— фактичне майбутнє постає як уже здійснене, порівн.: За два місяиі буде наша школа, але за умовою, що ви мені допоможете в цьому. I тоді вамого Михайлика врятовано (3. Тулуб) і под. Висловлене можна розцінювати як чергове свідчення експресивних можливостей презентного перфекта, його незалежності від контексту, що вказує на точку відліку;

- футуральні перфективи без особливих синтаксичних умов. Належність до майбутнього часового плану передбачає лише форма буде: - Про ваме поводження з арештованими буде повідомлено вашого безпосереднього начальника! (І. Смолич) - результатив буде повідомлено інформує про майбутню дію повідомляти $\rightarrow$ повідомити та їі результат повідомлений (повідомлено); Тим часом спокій в краю буде захитаний (Леся Українка) - результатив буде захитаний повідомляє про майбутню дію хитати $\rightarrow$ захитати та ії результат захитаний (захитано) тощо.

Існує думка, що форма результатива найскладніша для опису ${ }^{11}$. За свідченням дослідників, основною особливістю перфектного значення, а отже, i peзультативного значення зокрема, $є$ його ненаративність. Це означає неможливість використання результатива для позначення дій, що хронологічно слідують одна за одною, тобто результативи не включаються до видового контексту, на кшталт, „послідовність” 12 , зате їх включають до контексту типу „сукупність” зі значенням одночасних дій, що не слідують одна за одною.

Український результатив ілюструє ненаративність, позначаючи дії, що відбуваються одночасно, без хронологічної послідовності: Скільки люду там поховано, Невідомо, не полічено, Скільки вбито, покалічено (Д. Павличко); Який хаос в тій світлиці! Не метено, не прибрано; все порозкидане (І. НечуйЛевицький); Прибіг Роман, і повідомив, що забито п'ятеро коней $і$ потрощено його каруиу (О. Гончар); Степові маєтки, в яких минало ї̈ дівоцтво, попалено, розграбовано (О. Гончар) тощо.

Проте в українській мові функціонують і форми теперішнього доконаного, для яких характерна наративність, що організовує контекст на зразок „Послідовність”. Як свідчить аналіз фактичного матеріалу, наративних конструкцій не менше, ніж ненаративних результативних конструкцій, напр.: Для того й покладено, для того й залито цей клаптик асфальту, щоб і свої, $i$ - головне - приїжджі бачили, що й ми тут, у степах, не від темноти своєї на тягачах трясемось (О. Гончар); За що ж тебе, світе-брате, в своїй добрій, теплій хаті оковано, омурано, премудрого одурено, багряниями закрито і розп'ятієм добиmo? (Т. Шевченко); Скільки труда було покладено на виховання цих полум'яних юнаків, скільки пролито крові, скільки кращих з кращих чернігівиів, киян, полтавиів поховано з піснями або й просто кинуто мертвими на полях иієё трагічної Волині! (О. Довженко); Зверху помащено та притрущено червоним маком... (М. Коцюбинський); Поле поорано, поле заскороджено; Повне $i$ чисте зерно В землю, дощем перемиту, положено, Поки не встане воно (Я. Щоголів); Добре, що вкорочено вік Іслам-Гірею і посадовлено на ханський престол в Бахчисараї Магомет-Гірея (Н. Рибак); Одної ночі мене було спіймано на гарячому і приставлено перед очі намого боса (І. Муратов) і под.

3 наведених прикладів видно, як ненаративність, тобто здатність результатива позначати дії, які хронологічно слідують одна за одною, підтверджує,

${ }^{11}$ В. П. Недялков, Заметки по типологии результативных конструкицй, [в:] Его же, Коммуникативно-прагматические и семантические свойства речевых единии, Калинин 1980, c. $143-151$.

${ }^{12}$ В. П. Недялков, С. Е. Яхонтов, Указан. источник. 
що результатив не виражає ідеї дії в чистому вигляді, незалежно від результату дії, тому ненаративність уважаємо важливою семантичною ознакою результативного значення, залишаючи за наративністю, тобто здатністю результатива позначати ситуації зі значенням одночасних дій, що не зміняють одна одну, право репрезентувати дію і без збереженого результату.

Характерною особливістю категорії особи є і іï невласне-дієслівний характер $^{13}$. Семантичний зміст категорії особи становлять особа або предмет, що виконують дію або перебувають у станах, виразниками яких є дієслова. Виконавцем дії, носієм процесу чи стану може бути мовець, співрозмовник (слухач) або особа чи предмет, що не беруть безпосередньої участі в комунікативному акті. На цій основі вирізняють три грамеми категорії особи: 1) суб'єкт повідомлення (мовець); 2) адресат повідомлення (слухач); 3) об’єкт повідомлення.

Особливої уваги з огляду на зв’язок з категорією особи вимагають результативні форми на -но, -то. Зафіксовані приклади дають змогу класифікувати результативи за такими значеннями особи:

а) значення здійснення дії невизначеним суб'єктом: До картини було присунуто стілець, $і$ за знаком матушки Райси Санька злізла на нього (О. Донченко); - До нас скинуто зв'язкового Центрального партизанського штабу з шифром та дорученням. Прийде на старі, провалені явки (Ю. Яновський) тощо;

б) значення речовинного суб'єкта: природні явища чи стихія: На обрії, одразу ж за селом, де оболоню тишею сповито, горять кульбаби (В. Стус); імена зі значенням ,артефакт”: Прожекторами небо пописано (П. Тичина); Дивлюся ранком - вже заволочено серпанком сіреньким небо, далі став помалу й дощик накрапати (Леся Українка); метафоричні найменування: Повітрям тугим і червоним серия переповнено вщерть (В. Сосюра); Серие клекотом горя ошпарено (І. Драч); істота: Грядку изибулі було зрито кротом (С. Гуцало) тощо.

Усі наведені приклади містять агентивний додаток. Зазначимо, що як тільки агентивний додаток не фіксується, відразу 3'являється суб'єктна неоднозначність, напр. у реченні Пилюку піднято можливі значення особи і не-особи / істоти та не-істоти, а також значення довільності.

Щодо учасників мовної ситуації в аспектології аргументовано виділяють три основні персональні різновиди суб'єктної ситуації „діяч”:
а) діяч - мовець,
б) діяч - слухач,
в) діяч — третя особа.

Аналіз різних варіантів відношень мовця й слухача до дії (А. Ломов, В. Недялков, С. Яхонтов) уважається необхідним, оскільки традиційне розуміння категорії особи видається неадекватним. Так, в українських результативних конструкціях до кола можливих суб'єктів дії може включитися кожний учасник ситуації мовлення. Діячами постають:

а) мовець: Згадуючи усі сумніви, труднощзі і прикрості у процесі створення фільму, коли сиенарій уже затверджено $i$, як ведеться, вже „пронумеровано, прошнуровано й скріплено сургучною печаткою”, я приходжу до такого висновку: народ доручив нам свою кінодраматургію для того, щоб ми здобували в ній перемоги (О. Довженко); Ось уже перейдено пісок $і$ глину, $і$ корінь занурюється, як жадібний хробак, у жовту землю (Ю. Яновський) тощо;

\footnotetext{
${ }^{13}$ Там же, с. $150-155$.
} 
б) слухач: - Телеграму вже послано? - Послано (Ю. Яновський) і под.;

в) третя особа: Їм обом радісно стає, щзо знайдено спільну мову (О. Гончар); Воєвода слухав і не слухав. Закляк в очікуванні і неприступності. Забуто про все (П. Загребельний) та ін. — у цьому разі навантаження результатива посилено його вичленуванням в окреме висловлення.

Уживання результативних конструкцій на -но, -то з референцією до мовця характерне для наукового та публіцистичного стилів, де суб'єктом дії постає сам автор тексту: Включено також у монографію розгляд проблем текстової лінгвістики, щзо сьогодні набула поняттєво-категорійного апарату (А. Загнітко); Тут поставлено завдання зіставити функціонально тотожні синтаксичні структури (В. Русанівський) і под.

Отже, результативи переважно утворюються від транзитивних дієслів і зберігають водночас транзитивність. Одним із двох головних чинників, окрім транзитивності дієслів, від яких залежить можливість утворення результативних форм, є аспектуальна належність вихідного дієслова. Результативні форми утворені переважно від граничних і неграничних перфективних дієслів. Результативи від граничних і неграничних імперфективів характеризуються відсутністю факту кінця дії, проте залежно від контексту такі конструкції можуть набувати результативного значення. У рамах результативного значення розмежовуємо три темпоральні типи. Результативи аналітично виражають значення часу, яке виявлюване тільки формою дієслова бути, що отримує статус регулярного часового маркера. Українські результативні конструкції можуть бути особовими й неособовими, мати інклюзивний та ексклюзивний суб'єкти.

Проблема категорії результатива, незважаючи на тривалу історію її вивчення, залишається дискусійною. Дослідження категорії результатива є важливою ланкою в процесі розвитку вчення про дієслово, загальну структуру мови. 